\title{
Prediction Model of Balanced Nutrition Practices among University Students in the COVID-19 Outbreak
}

\author{
Yusma Indah ${ }^{1} \mathbb{D}$, Dian Inwana Ansyar ${ }^{1} \mathbb{D}$, Irviani Anwar Ibrahim ${ }^{1} \mathbb{D}$, Syarfaini Suyuti ${ }^{1}$ D, Diah Ayu Hartini ${ }^{2}$, \\ Nikmah Utami Dewi ${ }^{3 *}$ (i) \\ ${ }^{1}$ Department of Public Health, Faculty of Medicine and Health Science, Universitas Islam Negeri Alauddin Makassar, Gowa, \\ Indonesia; ${ }^{2}$ Department of Nutrition, Health Polytecnic of Palu, Palu, Indonesia; ${ }^{3}$ Department of Nutrition, University of Tadulako, \\ Palu, Indonesia
}



\begin{abstract}
AIM: Students included in the category of youth need balanced nutrition practices, especially during the COVID-19 outbreak. This study aims to determine the model of balanced nutrition behavior in youth in Gowa Regency, Makassar, Indonesia.

MATERIALS AND METHODS: This study was a quantitative study with a cross-sectional study, in which primary data were collected from June to July 2020. The respondents were 597 students at public and private universities located in Gowa Regency who filled the questionnaires.

RESULTS: The bivariate analysis results, which were based on the respondents' characteristics, showed that only age significantly affected balanced nutrition practices $(p=0.048)$. Based on the independent variables studied, poor knowledge $\left(p=0.000, \mathrm{OR}_{\mathrm{cos}}=2.229[\mathrm{Cl} 1.601-3.105]\right)$ and poor attitude $\left(\mathrm{p}=0.001, \mathrm{OR}_{\mathrm{orde}}=1.735[\mathrm{Cl} 1.250-2.409]\right)$ obtained a significant correlation with poor balanced nutrition practices. The final model of balanced nutrition practices using multivariate analysis indicated that knowledge was the biggest predictor of balanced nutrition $(p=0.000$ $\mathrm{OR}=2.067[\mathrm{Cl} 1.476-2.893])$. The number implied that respondents with good knowledge had 2.067 times the opportunity to take balanced nutrition practices than those with less knowledge after controlling for age and attitude variables.
\end{abstract}

CONCLUSION: Producing well-balanced nutrition behavior requires well-balanced nutrition knowledge, including university students who belong to the late adolescent stage.

\section{Introduction}

Adolescence is the transitional age group from childhood to young adolescence and adulthood. Essential conditions that affect the nutritional needs of this group include rapid growth while entering the age of puberty, eating habits, menstruation, and the attention to the physical appearance of body image, especially in young women. Thus, the calculation of the nutritional needs, including balanced nutrition in this group, must pay attention to these conditions. For young women, notably, more attention should be paid to their preparation before marriage [1].

Students whose ages belong to the adolescence group are the same. Those with busy activities, such as lectures, work on assignments and exams, field activities, student activities, and other activities, require the fulfillment of balanced nutrition, specifically during the current COVID-19 outbreak. A prior study discovered that more than half of students had proper knowledge related to balanced nutrition, however, only a tiny part of the sample applied a good consumption pattern with rice, chicken, and coconut oil as the types of food ingredients that are often consumed [2]. Students also eating more during the pandemic, increased consumption of snacks, and increased consumption of vegetables and fruit [3], [4].

Knowledge affects behavior change by providing a favorable understanding and great trust in the information obtained so that the subject's behavior can shift through changes in their attitudes [5], [6]. However, this is not always the case. Several studies have shown that knowledge influences shifting in eating behavior regardless attitudes being change [7], [8]. On the other hand, attitudes are related to changes in behavior without being accompanied by a relationship between knowledge and behavior [9], [10].

Based on the background elucidated above, it can be argued that the predictive model for balanced nutrition of students during the COVID-19 outbreak should be studied to provide more information on students' balanced nutritional behavior. 


\section{Methods}

This study is a quantitative study with a cross-sectional design, in which primary data were collected from June to July 2020. The data were collected through an online questionnaire distributed through WhatsApp from June 17 to July 19, 2020. The respondents were students of public and private universities in Gowa Regency, Makassar, Indonesia, with informed consent describing a refusal to be a resident respondent as the exclusion criteria. In total, students who filled the questionnaire were 597, while three respondents were excluded. In other words, it can be stated that the total sample was 597 residents from seven universities in Gowa Regency.

The online questionnaire consisted of four parts, namely demographic characteristics, knowledge, attitudes, and practices of balanced nutrition. The time to answer the online questionnaire is a maximum of $20 \mathrm{~min}$. The respondents' answers were first scored before being analyzed. It was then accumulated to determine the cut-off point through the mean value. Knowledge, attitude, and practice variables in this study were divided into 2 categories. Respondents who answered correctly $50 \%$ of the number of questions on the questionnaire were included in the "poor" category, while respondents who answered correctly $>50 \%$ of the total questions were included in the categories of "good" knowledge, attitude, and practice.

The independent variables of this study were knowledge and attitude toward balanced nutrition, while the practice of balanced nutrition was the dependent variable. The demographic variable, moreover, was supposed to be a potential confounder variable; however, it was according to the final model after the multivariate analysis had been done. The data were analyzed through frequency for the univariate analysis, chi-square for the bivariate analysis, and logistic regression for the multivariate analysis to find the final model correlation of knowledge toward the practice of preventive action among students after controlling the potential confounder variable.

\section{Results}

The sample was 597 productive people, primarily female $(86.8 \%)$, age $>21(63.8 \%)$, with the average family income above or equal to the minimum wage $(52.4 \%)$. Besides, during the pandemic, most of them live together with their parents $(75.4 \%)$ or siblings (54.3\%). Based on the information on balanced nutrition, the most respondents were identified with good knowledge $(54.4 \%)$, attitudes $(54.1 \%)$, and practices $(57.6 \%)$, which can be further seen in the Table 1.
Table 1: Frequency distribution of demographic characteristics, knowledge, attitudes, and practices related to balanced nutrition $(n=597)$

\begin{tabular}{|c|c|c|}
\hline Variables & $\mathrm{n}$ & $\%$ \\
\hline \multicolumn{3}{|l|}{ Sex } \\
\hline Male & 79 & 13.2 \\
\hline Female & 518 & 86.8 \\
\hline \multicolumn{3}{|l|}{ Age (years old) } \\
\hline 15-21 & 216 & 36.2 \\
\hline$>21$ & 381 & 63.8 \\
\hline \multicolumn{3}{|l|}{ Father's education } \\
\hline SJunior high school & 152 & 25.5 \\
\hline > Junior high school & 445 & 74.5 \\
\hline \multicolumn{3}{|l|}{ Mother's education } \\
\hline$\leq$ Junior high school & 167 & 28.0 \\
\hline > Junior high school & 430 & 72.0 \\
\hline \multicolumn{3}{|l|}{ Father's occupation } \\
\hline Farmer/laborer & 194 & 32.5 \\
\hline Self-employed & 248 & 41.5 \\
\hline Civil servant & 155 & 26.0 \\
\hline \multicolumn{3}{|l|}{ Mother's occupation } \\
\hline Housewife & 395 & 66.2 \\
\hline Farmer/laborer & 9 & 1.5 \\
\hline Self-employed & 64 & 10.7 \\
\hline Civil servant & 129 & 21.6 \\
\hline \multicolumn{3}{|l|}{ Family income (per month) } \\
\hline <Regional Minimum Wage (UMR) & 284 & 47.6 \\
\hline ?Regional Minimum Wage (UMR) & 313 & 52.4 \\
\hline \multicolumn{3}{|l|}{ Who do you live with during the pandemic } \\
\hline Rented house & 33 & 5.5 \\
\hline Family & 114 & 19.1 \\
\hline Parents & 450 & 75.4 \\
\hline \multicolumn{3}{|l|}{ Number of siblings (people) } \\
\hline$>3$ & 324 & 54.3 \\
\hline$\leq 2$ & 273 & 45.7 \\
\hline \multicolumn{3}{|l|}{ Breakfast habits per week (times) } \\
\hline$>3$ & 216 & 36.2 \\
\hline $0-3$ & 381 & 63.8 \\
\hline \multicolumn{3}{|l|}{ Lunch habits per week (times) } \\
\hline$>3$ & 291 & 48,7 \\
\hline $0-3$ & 306 & 51.3 \\
\hline \multicolumn{3}{|l|}{ Dinner habits per week } \\
\hline$>3$ times & 275 & 46.1 \\
\hline $0-3$ times & 322 & 53.9 \\
\hline \multicolumn{3}{|l|}{ Snack consumption (times/week) } \\
\hline$>3$ & 344 & 57.6 \\
\hline$\leq 3$ & 253 & 42.4 \\
\hline \multicolumn{3}{|l|}{ What order are you in the family } \\
\hline$>2$ & 179 & 30.0 \\
\hline 2 & 160 & 26.8 \\
\hline 1 & 258 & 43.2 \\
\hline \multicolumn{3}{|l|}{ Balanced nutrition knowledge } \\
\hline Poor & 272 & 45.6 \\
\hline Good & 325 & 54.4 \\
\hline \multicolumn{3}{|l|}{ Balanced nutrition attitude } \\
\hline Poor & 274 & 45.9 \\
\hline Good & 323 & 54.1 \\
\hline \multicolumn{3}{|l|}{ Balanced nutrition practices } \\
\hline Poor & 253 & 42.4 \\
\hline Good & 344 & 57.6 \\
\hline
\end{tabular}

\section{Characteristics of respondents based on} balanced nutrition practices

The results showed that only age significantly affected the balanced nutrition practices ( $p=0.048)$, while other demographic aspects were insignificant, as shown in Table 2.

\section{Knowledge and attitude toward balanced nutrition practices}

The bivariate analysis indicated that knowledge $(p=0.000)$ and attitude $(p=0.001)$ brought a significant effect on balanced nutrition practices (Table 3 ).

\section{Final models of balanced nutrition practice}

The results of the multivariate analysis on knowledge as a variable disclosed that the most 
Table 2: Demographic characteristics and practices related to balanced nutrition $(n=597)$

\begin{tabular}{|c|c|c|c|c|c|c|}
\hline \multirow[t]{3}{*}{ Characteristics } & \multicolumn{4}{|c|}{ Practice } & \multirow[t]{3}{*}{$\mathrm{OR}_{\text {crude }}(95 \% \mathrm{Cl})$} & \multirow[t]{3}{*}{$\mathrm{p}$-value } \\
\hline & \multicolumn{2}{|l|}{ Poor } & \multicolumn{2}{|c|}{ Good } & & \\
\hline & $\mathrm{n}$ & $\%$ & $n$ & $\%$ & & \\
\hline \multicolumn{7}{|l|}{ Sex } \\
\hline Male & 30 & 38.0 & 49 & 62.0 & $0.810(0.498-1.317)$ & \multirow[t]{2}{*}{0.395} \\
\hline Female & 223 & 43.1 & 295 & 56.9 & 1 & \\
\hline \multicolumn{7}{|l|}{ Age (years old) } \\
\hline $15-21$ & 103 & 47.7 & 113 & 52.3 & $1.404(1.002-1.966)$ & \multirow[t]{2}{*}{0.048} \\
\hline$>21$ & 150 & 39.4 & 231 & 60.6 & 1 & \\
\hline \multicolumn{7}{|l|}{ Father's education } \\
\hline SJunior high school & 65 & 42.8 & 87 & 57.2 & $1.021(0.704-1.482)$ & \multirow{2}{*}{0.912} \\
\hline >Junior high school & 188 & 42.2 & 257 & 57.8 & 1 & \\
\hline \multicolumn{7}{|l|}{ Mother's education } \\
\hline$\leq$ Junior high school & 77 & 46.1 & 90 & 53.9 & $1.235(0.862-1.770)$ & \multirow[t]{2}{*}{0.251} \\
\hline >Junior high school & 176 & 40.9 & 254 & 59.1 & 1 & \\
\hline \multicolumn{7}{|l|}{ Father's occupation } \\
\hline Farmer/laborer & 87 & 44.8 & 107 & 55.2 & $1.287(0.838-1.978)$ & \multirow[t]{3}{*}{0.509} \\
\hline Self-employed & 106 & 42.7 & 142 & 57.3 & $1.182(0.785-1.780)$ & \\
\hline Civil servant & 60 & 38.7 & 95 & 61.3 & 1 & \\
\hline \multicolumn{7}{|l|}{ Mother's occupation } \\
\hline Housewife & 166 & 42.0 & 229 & 58.0 & $0.975(0.652-1.458)$ & \multirow[t]{4}{*}{0.908} \\
\hline Farmer/laborer & 3 & 33.3 & 6 & 66.7 & $0.673(0.161-2.809)$ & \\
\hline Self-employed & 29 & 45.3 & 35 & 54.7 & $1.115(0.610-2.038)$ & \\
\hline Civil servant & 55 & 42.6 & 74 & 57.4 & 1 & \\
\hline \multicolumn{7}{|l|}{ Family income (monthly) } \\
\hline$<$ UMR & 114 & 40.1 & 170 & 59.9 & $0.839(0.606-1.162)$ & \multirow[t]{2}{*}{0.292} \\
\hline$\geq U M R$ & 139 & 44.4 & 174 & 55.6 & 1 & \\
\hline \multicolumn{7}{|c|}{ Who do you live with during the pandemic } \\
\hline Rented house & 19 & 57.6 & 14 & 42.4 & 0.519 & 0.190 \\
\hline Family & 48 & 42.1 & 66 & 57.9 & 0.969 & \\
\hline Parents & 186 & 41.3 & 264 & 58.7 & 1 & \\
\hline Number of siblings (pec & & & & & & \\
\hline$>3$ & 110 & 40.3 & 163 & 59.7 & $0.854(0.616-1.184)$ & 0.344 \\
\hline$\leq 2$ & 143 & 44.1 & 181 & 55.9 & 1 & \\
\hline What order are you in th & & & & & & \\
\hline$>2$ & 81 & 45.3 & 98 & 54.7 & $1.926(0.942-3.939)$ & 0.605 \\
\hline 2 & 64 & 40.0 & 96 & 60.0 & $1.032(0.681-1.566)$ & \\
\hline 1 & 108 & 41.9 & 150 & 58.1 & 1 & \\
\hline Breakfast habits per we & & & & & & \\
\hline$>3$ & 82 & 38.0 & 134 & 62.0 & $0.752(0.534-1.057)$ & 0.100 \\
\hline $0-3$ & 171 & 44.9 & 210 & 55.1 & 1 & \\
\hline Lunch habits per week & & & & & & \\
\hline$>3$ & 118 & 40.5 & 173 & 59.5 & $0.864(0.624-1.196)$ & 0.378 \\
\hline $0-3$ & 135 & 44.1 & 171 & 55.9 & 1 & \\
\hline Dinner habits per week & & & & & & \\
\hline$>3$ & 117 & 42.5 & 158 & 57.5 & $1.013(0.731-1.403)$ & 0.939 \\
\hline $0-3$ & 136 & 42.2 & 186 & 57.8 & 1 & \\
\hline Snack consumption (tim & & & & & & \\
\hline$>3$ & 151 & 43.9 & 193 & 56.1 & $1.158(0.833-1.610)$ & 0.382 \\
\hline$\leq 3$ & 102 & 40.3 & 151 & 59.7 & 1 & \\
\hline
\end{tabular}

significant predictor factor for balanced nutrition practices was OR $(95 \% \mathrm{Cl})=1.354(1.476-2.893)$ with $p=0.000$. The number further indicated that respondents with good knowledge had 2.067 times the opportunity to carry out balanced nutrition practices than respondents with less knowledge after being controlled with age and attitude variables.

Table 3: Knowledge and attitude toward balanced nutrition practices using Chi-square $(n=597)$

\begin{tabular}{|c|c|c|c|c|c|c|}
\hline \multirow[t]{3}{*}{ Variable } & \multicolumn{4}{|c|}{ Practice } & \multirow{3}{*}{$\mathrm{OR}_{\text {crude }}(95 \% \mathrm{Cl})$} & \multirow[t]{3}{*}{$p$-value } \\
\hline & \multicolumn{2}{|c|}{ Poor } & \multicolumn{2}{|c|}{ Good } & & \\
\hline & $\mathrm{n}$ & $\%$ & $\mathrm{n}$ & $\%$ & & \\
\hline \multicolumn{7}{|c|}{ Knowledge } \\
\hline Poor & 114 & 52.9 & 128 & 47.1 & \multirow[t]{2}{*}{$2.229(1.601-3.105)$} & \multirow[t]{2}{*}{0.000} \\
\hline Good & 109 & 33.5 & 216 & 66.5 & & \\
\hline \multicolumn{7}{|l|}{ Attitude } \\
\hline Poor & 136 & 49.6 & 138 & 50.4 & \multirow[t]{2}{*}{$1.735(1.250-2.409)$} & \multirow[t]{2}{*}{0.001} \\
\hline Good & 117 & 36.2 & 206 & 63.8 & & \\
\hline
\end{tabular}

The other multivariate analysis performed on attitude also showed predictor factors for balanced nutrition practices of OR $(95 \% \mathrm{Cl})=1.600(1.143-2.240)$ with $p=0.006$. In other words, it can be argued that respondents with good attitudes had 1.600 times the opportunity to take balanced nutrition practices than respondents whose attitudes were less after being controlled with age and knowledge variables. As for those that showed predictor factors for balanced nutrition practices, the OR is $(95 \% \mathrm{Cl})=1.358(0.960-1920)$ with $\mathrm{p}=0.084$, which pointed out that respondents aging more than 21 years old had 1.358 times the opportunity to take balanced nutrition practices compared to respondents aging 15-21 years old after being controlled with attitude and knowledge variables (Table 4).

\section{Discussion}

\section{Balanced nutrition practices}

The balanced nutrition practice is a practice that includes a diet with components of vegetables, fruit, vegetable protein, and animal protein, which is under the pillars of balanced nutrition. Balanced nutrition practices questions also include the consumption of sweet, salty, and fatty foods, physical activity patterns, and handwashing behavior before eating under the balanced nutrition guidelines during the COVID-19 outbreak. Based on the analysis, this study discovered that teenagers with good practices toward balanced nutrition were as much as $57.6 \%$, which proved that most teenagers already know that balanced nutrition practices are indispensable in maintaining body 
Table 4: Full and final predictive models of balanced nutrition practice

\begin{tabular}{|c|c|c|c|c|c|c|}
\hline \multirow[t]{2}{*}{ Variable } & \multicolumn{2}{|l|}{ Full model } & \multicolumn{2}{|l|}{ Final model } & \multirow[t]{2}{*}{ Coefficient (B) } & \multirow[t]{2}{*}{ S.E } \\
\hline & $\begin{array}{l}\text { Adjusted OR } \\
(95 \% \mathrm{Cl})\end{array}$ & p-value & $\begin{array}{l}\text { Adjusted OR } \\
(95 \% \mathrm{Cl})\end{array}$ & p-value & & \\
\hline \multicolumn{7}{|l|}{ Age (years old) } \\
\hline $15-21$ & $1.383(0.976-1.960$ & 0.068 & $1.358(0.960-1.920)$ & 0.084 & 0.306 & 0.177 \\
\hline$>21$ & 1 & & 1 & & & \\
\hline \multicolumn{7}{|l|}{ Attitude } \\
\hline Poor & $1.591(1.135-2.230)$ & 0.007 & $1.600(1.143-2.240)$ & 0.006 & 0.470 & 0.172 \\
\hline Good & 1 & & 1 & & & \\
\hline \multicolumn{7}{|l|}{ Knowledge } \\
\hline Poor & $2.018(1.439-2.831)$ & 0.000 & $2.067(1.476-2.893)$ & 0.000 & 0.726 & 0.172 \\
\hline Good & 1 & & & & & \\
\hline \multicolumn{7}{|c|}{ Breakfast Habits per week (times) } \\
\hline$>3$ & $0.792(0.556-1.128)$ & 0.196 & - & - & - & - \\
\hline $0-3$ & 1 & & & & & \\
\hline \multicolumn{7}{|c|}{ Who do you live with during the pandemic } \\
\hline Rented house Family & $1.741(0.832-3.642)$ & 0.141 & - & - & - & - \\
\hline Parent & $1.011(0.657-1.555)$ & 0.961 & & & & \\
\hline Constanta & 1 & & & & -0.981 & 0.153 \\
\hline
\end{tabular}

immunity, especially during the COVID-19 outbreak. Furthermore, consuming foods with balanced and safe nutrition can improve the immune system and reduce the risk of chronic diseases and infectious diseases [11].

Even so, many adolescents have not implemented a well-balanced diet due to several factors, such as living alone in a boarding house so that the application of balanced nutrition is not well-maintained. Maintaining a good and healthy diet is vital during pandemics, including COVID-19. Although no food or dietary supplement can prevent coronavirus transmission, changing diet by consuming a healthy, balanced diet is essential in increasing an excellent immune system [12].

\section{Predictive modeling of balanced nutrition}

\section{practices}

The final predictive modeling demonstrated that the predictors of balanced nutrition practices in adolescents during the COVID-19 outbreak were age, knowledge, and attitudes related to the application of balanced nutrition.

The formula for the predictive model of Balanced Nutrition Practice use regresion equation is as follow:

$y=$ constant $+b 1 \times 1+b 2 x 2+\ldots .+b i x i$

The logit model for balanced nutrition practice $=-0.981+0.306^{*}$ age $+0.47^{*}$ attitude $+0.726^{*}$ Knowledge. If a 15-21 year old, has a poor attitude and knowledge, the prediction of probability that individu have the poor balanced nutrition practice is

$$
\operatorname{In}\left(\frac{p}{1-p}\right)=a+b_{1} x_{1}+b_{2} x_{2}+\ldots \ldots \ldots \ldots+b_{k} x_{k}
$$

$$
P=\frac{1}{1+\exp ^{-(y)}}
$$

$$
P=\frac{1}{1+\exp ^{-(0.521)}}
$$

$$
P=\frac{1}{1.594}
$$

$$
P=0.627 \text { or } 62.7 \%
$$

The formulated model stipulated that if all predictors were "Yes $=1$," it could predict a $62.7 \%$, which means that the predictor variable had a high contribution in predicting the outcome, namely balanced nutrition practices.

Knowledge of balanced nutrition will determine attitudes and practices related to the application of balanced nutrition, especially during the COVID-19 outbreak, which requires maximum prevention. One of the preventions, moreover, can be done by consuming a balanced diet. Most of the teenagers who were the sample of this study had good knowledge about balanced nutrition and implementing balanced nutrition practices. Thus, the results showed a significant relationship between adolescent knowledge and balanced nutrition practices during the COVID-19 outbreak.

OR value of knowledge is higher than attitudes related to balanced nutrition practices in this research. The student proportion of poor knowledge and practices is higher than student proportion of poor attitudes and practices. The proportion of student with good knowledge and practices is also higher than student who have good attitudes and practices. Good knowledge of balanced nutrition in this study aligns with the previous research [13]. Excellent knowledge, 
furthermore, is the main thing in determining the selection of foods according to balanced nutrition. In other words, by having good knowledge about healthy food, adolescents know more about arranging a healthy food menu and thereby can regulate their diet in various ways and accordance with balanced nutrition guidelines. This way, immunity can be maintained, and the body is protected from infectious diseases [14].

The final multivariate model, however, did not include the sex, parents' education and occupation, family income, living status, number of siblings, breakfast habits, lunch habits, dinner habits, and snack consumption.

\section{practices}

\section{Factors associated with balanced nutrition}

The age and attitude of adolescents toward the application of balanced nutrition are predictors in addition to the knowledge related to balanced nutrition practices. In addition, adolescents aged 15-21 years old have a higher percentage of implementing poorly balanced nutrition $(47.7 \%)$ than adolescents aged $>21$ years old. In contrast, adolescents aged $>21$ years old had a higher percentage of well-balanced nutrition (60.6\%) than adolescents aged 15-21 years old. Teenagers are generally still unstable and easily influenced - the knowledge they have cannot simply be applied in their daily lives due to the influence of friends, family, and the environment [15]. Age in this study, moreover, has a positive relationship with balanced nutrition, where the older the age, the more proportional the balanced nutrition practice [16].

Based on balanced nutrition practices, adolescents who have poor attitudes also had poor balanced nutrition practices. The percentage of adolescents with poor attitudes and practices was $49.6 \%$, while those with good attitudes and practices toward well-balanced nutrition reached $63.8 \%$. The attitude toward positive, balanced nutrition practices will result in positive practices and affect a person's nutritional status [17]. However, other study found that subjects had good behavior even though their knowledge was lacking and their attitudes were negative [18]. Person's behavior is not only influenced by knowledge and attitudes, which are predisposing factors for behavior changes, but also by enabling factors (availability of facilities and infrastructure) as well as reinforcing factors, such as the influence of community leaders and people who are considered necessary, namely health workers and other laws [19].

\section{Conclusion}

In conclusion, the age as a respondent's characteristic and the attitude and knowledge variables were predictors of balanced nutrition practices during the COVID-19 outbreak. Furthermore, age 15-21 and lack of attitude and knowledge were predictors of poorly balanced nutrition. These variables would arguably directly affect other variables such as breakfast, lunch, dinner habits, and snack consumption per week.

After analyzing all the mentioned variables, in the end, it can be confirmed that the final predictive modeling of balanced nutrition practices using multivariate analysis shows that knowledge is the most significant predictor of balanced nutrition. In other words, the respondents with good knowledge have 2.067 times the opportunity to carry out balanced nutrition practices than respondents with less knowledge after controlling age and attitude variables. Thus, good knowledge of balanced nutrition is also needed for adolescent students to produce good balanced nutritional behavior.

\section{References}

1. Kemenkes RI. Regulation of the Minister of Health of the Republic of Indonesia Number 41 of 2014 Concerning Balanced Nutrition; 2014. p. 1-96.

2. Wayan N, Witari S, Dewa I, Sudjana N, Suarjana IM, Gizi AJ, et al. Balanced Nutrition Consumption Behavior of Students in the Department of Nutrition, Denpasar Health Polytechnic; 2015. p. 75-89.

3. Noviasty R, Susanti R. Changes in eating habits of nutrition students during the COVID 19 pandemic. J Kesehat Masy Mulawarman. 2020;2(2):90.

4. Luo Y, Chen L, Xu F, Gao X, Han D, Na L. Investigation on knowledge, attitudes and practices about food safety and nutrition in the China during the epidemic of Corona virus disease 2019. Public Health Nutr. 2021;24(2):267-74. https:// doi.org/10.1017/s1368980020002797 PMid:32669149

5. Zhu X, Xie X. Effects of knowledge on attitude formation and change toward genetically modified foods. Risk Anal. 2015;35(5):790-810. https://doi.org/10.1111/risa.12319 PMid:25693867

6. Ghosh S, Kabir MR, Alam MR, Chowdhury Al, Al Mamun MA Balanced diet related knowledge, attitude and practices (KAP) among adolescent school girls in Noakhali district, Bangladesh: A cross sectional study. Int J Adolesc Med Health. 2020. https:// doi.org/10.1515/ijamh-2020-0106

PMid:32887187

7. Iradukunda D, Ngomi N. Knowledge, attitude and practices towards nutrition and influencing factors among pregnant and lactating women in Kigeme Refugee Camp, Rwanda. Galore Int J Health Sci Res. 2011;5(2):98.

8. Bakhtiar M, Masud-Ur-Rahman M, Kamruzzaman M, Sultana N Rahman SS. Determinants of nutrition knowledge, attitude and practices of adolescent sports trainee: A cross-sectional study in Bangladesh. Heliyon. 2021;7(4):e06637. https://doi. org/10.1016/j.heliyon.2021.e06637

PMid:33898807

9. Kigaru DM, Loechl C, Moleah T, Macharia-Mutie CW, Ndungu ZW. Nutrition knowledge, attitude and practices among urban primary school children in Nairobi City, Kenya: A KAP study. BMC Nutr. 2015;1(1):44. https://doi.org/10.1186/ 


\section{s40795-015-0040-8}

10. Dewi NU, Hardinsyah, Hartini DA, Pradana F, Bohari. Literature review: The effect of nutrition education on knowledge, attitude, and nutrition practice on adolescents in Indonesia. Int $J$ Psychosoc Rehabil. 2020;24(10):2016-23.

11. Kemenkes RI. Guide to Balanced Nutrition During COVID-19; 2020.

12. Akbar DM, Aidha Z. The implementation of balanced nutrition behaviour of Binjai city society during the 2020 COVID-19 pandemic. J Menara Med. 2020;3(1):15-21.

13. Selaindoong SJ, Amisi MD, Kalesaran AFC, Kesehatan F, Universitas M, Ratulangi $S$, et al. Description of nutrition knowledge of fourth semester students of the faculty of public health, Sam Ratulangi University during the social restrictions in COVID-19 pandemic. J KESMAS. 2020;9(6):8-16. https://doi. org/10.26911/theicph.2017.159

14. Ramadhani $\mathrm{K}$, Khofifah $\mathrm{H}$. Balanced nutrition education as an effort to increase adolescent knowledge in Bedingin Wetan village during pandemic COVID-19. ??? 2021;4(2):66-74.

15. Tepriandy S, Rochadi RK. Relationship between knowledge and attitude with nutritional status of MAN medan students during the COVID-19 pandemic. TROPHICO Trop Public Health J. 2021;1(1):43-9.

16. Yoshida Y, Scribner R, Chen L, Broyles S, Phillippi S, Tseng TS. Diet quality and its relationship with central obesity among Mexican Americans: Findings from National health and nutrition examination survey (NHANES) 1999-2012. Public Health Nutr. 2017;20(7):1193-202. https://doi.org/10.1017/ s1368980016003190

PMid:27974064

17. Fajriani F, Aritonang EY, Nasution Z. Relationship of knowledge, attitudes and practice of balanced nutrition among family with the nutritional status of toddlers age 2-5 years. J IImu Kesehat Masy. 2020;9(1):1-11.

18. Fatharanni MO, Angraini DI, Oktaria D. Relationship between knowledge, attitudes and behavior related to balanced nutrition with nutritional status in fertile women in Terbanggi Besar district, Central Lampung Regency. Medula. 2019;9(50):26-37.

19. Notoadmodjo S. Health Promotion and Health Behavior Revised Edition. Rineka Cipta; 2012 